\title{
Sustainable Development Goals and Social Work: Opportunities and Challenges for Social Work Practice in Malaysia
}

\author{
Denison Jayasooria ${ }^{1}$
}

Published online: 3 March 2016

(C) Springer International Publishing 2016

\begin{abstract}
The global agenda of Sustainable Development Goals (SDGs) provides Social Workers an opportunity to redefine their role pertaining to people empowerment, socioeconomic development, human rights and the environment. This is especially so for Social Workers in Malaysia whose roles have been narrowly defined in the past. The Global Agenda enhances these possibilities for Social Workers as the SDG goals and values have parallels relevance and application with Social Work practice. However, there are challenges too, as Social Work practice addressing both human rights and environmental concerns address structural issues viewed as politically sensitive and therefore might be confrontational in nature. Nonetheless, Social Workers must stand alongside their service users as partners in development and address issues of injustice and inequality courageously and uncompromisingly abiding by Social Work Principles and Values.
\end{abstract}

Keywords Sustainable Development Goals · Social Work · Human Rights · Inclusive Development · Bottom 40\% .

Malaysia

\section{Introduction}

The global community at the United Nations on September 25, 2015 agreed to the 2030 Global Agenda entitled 'Transforming our world: The 2030 Agenda for sustainable Development'. This action plan which replaces the Millennium Development

Denison Jayasooria

denisonsocialworkmalaysia@gmail.com

1 Principal Research Fellow, Institute of Ethnic Studies (UKM), Bangi, Malaysia
Goals (MDGs) is universal in nature and comprehensive in the range of issues and concerns addressed pertaining to development, economy, human rights and the environment. The theme of 'no one will be left behind' is most critical so as to ensure that inclusive development is within the reach of all people groups and communities.

It is in this global context that in this article, Sustainable Development Goals (SDGs) are discussed from a social work practice point of view and with a strong commitment to human rights issues in Malaysia. It is argued that the SDGs provide social workers a good and holistic intervention framework for practice as there are both new opportunities and challenges for social workers. Lessons learned in this context have implications for social work practice in Malaysia and elsewhere. Adopting a human rights approach to social work practice is of utmost importance as it is founded on the inalienable rights of the human person. The SDG global agenda enables social workers to utilise this approach based on the global commitment through the 2030 agenda which is focused on development, human rights and environment.

This article is divided into five parts. The first is a focus on the SDGs and a discussion of the key features. The second concerns social work and SDGs noting the links and synergies in the context of social work values. The third links to Malaysia and the SDGs' relevance and concerns in terms of public policies pertaining to inclusive development. The fourth section focuses on human rights issues and concerns pertaining to SDGs from Malaysia's ratification of UN conventions. While a conservative approach is adopted on human rights matters, the ratification of three conventions provides some room for public advocacy and lobby for compliance based on international standards. The final section concerns social work challenges and opportunities with specific reference to Malaysia and how social workers could utilise the SDG thrust to champion the concerns of their service users 
through community empowerment strategies and policy advocacy on the national stage.

Sachs (2015) writes that a good society is not only an economically prosperous society (with high per capital income) but also one that is socially inclusive, environmentally sustainable and well governed' ( $p$ 12). In this context, social workers promote the building of a good society especially for the vulnerable sections of society who often get neglected in the process. It is therefore our objective to understand the SDG agenda and find our place as professional social workers in building a better society for all people.

\section{SDG}

The SDGs were formulated through an extension participatory process - the collective journey from high level panels to open working groups with lots of consultations and finally a draft negotiated document agreed upon the State players.

The post Millennium Development Goals (MDGs) review process began at Rio plus 20 (June 2012) where the document The Future We Want was released (UN: Rio plus 20). After this, the UN established a high level panel in July 2012, to advise the world leaders on the global development framework beyond 2015. They produced a report entitled 'A New Global Partnership: Eradicate Poverty and Transform Economies through Sustainable Development' (UN: High Level Panel). This was followed by an Open working group for SDG which was established in July 2013 (UN: Open Working Group), and this global participatory process produced a report on Proposals for SDG by July 2014.

By December 2014, the UN Secretary General Report Synthesis Report 'The Road to Dignity by 2030: Ending Poverty, Transforming All Lives and Protecting the Planet' was released. By August 3, 2015, a draft SDG Agenda document entitled 'Transforming our world: the 2030 Agenda for Sustainable Development' was circulated after a lengthy global discussion among all the stakeholders. There was a strong collective process, and civil society was part of this formulation process although the dominant players were the member states. All these documents were freely accessible on the UN website, and therefore, this formulation process was inclusive and transparent.

The 2030 SDG Agenda has five areas of critical importance which can be referred to as the five Ps. These are people, planet, prosperity, peace and partnerships. The first $\mathrm{P}$ is PEOPLE and is the heart of development to promote human dignity, well-being of all, combat inequalities, end poverty and gender equality. The second P is PLANET - and champions combating climate change, promoting sustainable use of earth's resources and sustainable patterns of consumption and production. The third P, PROSPERITY, specifically focuses on inclusive and sustainable economic growth. The fourth $\mathrm{P}$ is PEACE - promote life free from fear, coercion and violence, access to justice and human rights for all, and the final $P$, PARTNERSHIP, calls for global solidarity and peoplecentred approach to development. All these are at the heart of social work theory and practice as can be seen by the IFSW/ IASSW definition of social work (IFSW 2014).

The 2030 Global Transformation Agenda has 17 goals and 169 specific targets. It is noted that the SDGs will provide a more comprehensive framework in addressing the concerns of the Bottom $40 \%$ (B40) of the socio-economic divide, ensuring not just equal access but also outcomes. The SDGs build on a strong commitment to people-centred development, human rights and environmental sustainability. The agenda focuses on human rights and environment and not just on development concerns. This is a global agenda for the next 15 years - 2016 to 2030 . Each nation state or country has the primary responsibility for financial resources mobilization and capacity building. There will be a global financing for development agenda. In addition, there will be a new partnership between the private sector and civil society in this sustainable development agenda.

\section{Social Work and SDG}

Social workers can relate to this Agenda 2030 at the national, regional and global levels. The SDGs bring an interconnected understanding of human needs and concerns that are economic, social and environmental. Reference is made in the 2030 Agenda to terms such as 'deep interconnection \& many crosscutting elements across the goals and targets' (United Nations 2015). Furthermore, a more holistic and sustainable way of addressing human need is promoted through tackling poverty, education, health, economy and employment which are all human development concerns.

The International Federation of Social Workers, the International Association of Schools of Social Work and the International Council on Social Welfare jointly initiated a global agenda between 2012 and 2016 (IFSW 2014). In 2010 at Hong Kong, an extensive consultative process began at a joint conference and this culminated in specific commitments to action. A joint publication entitled 'The Global Agenda for social work and social development commitment to action' was developed.

In this exercise, the three global organisations agreed to support the UN in the preparation of the post 2015 development agenda. At the global campaign level, the three global organisations agreed to undertake five strategies, namely promote social and economic equalities, ensure the dignity and worth of the persons, promote sustainable communities and environmentally sensitive development, promote well-being through sustainable human relationships, and ensure an appropriate environment for practice and education. The organisations jointly stated 'we would strive with others for a peoplefocused global economy that is regulated to protect and 
promote social justice, human rights and sustainable development' (IFSW 2014, p 3). They also pledged that their organisations will 'promote education and practice standards in social work and social development that enabled workers to facilitate sustainable social development outcomes' (IFSW 2014, p 3).

There was a strong global agenda in working alongside the UN formulation process. However, at the Malaysia level, social workers were not very active in this process and therefore left the national, regional and international organisations to play this role. In the post- 2015 period, there is still a necessity for grassroots organisations and social workers to reflect on the global process and to know how their practice can be guided by this global vision and agenda of SDGs. IFSW rightly identified that 'social work and social development practitioners are not normally involved in global, macroeconomic decisions. However practitioners do bear witness to their social consequences and realities on a daily basis and have a duty to provide feedback about the outcomes of social policies' (IFSW 2014, p 5).

The human rights approach adopted in the SDGs especially in defining the issues as well as governing implementation has relevance for social work profession. Earlier, the UN Centre for Human Rights in cooperation with IFSW \& IASSW published a Human Rights \& Social Work professional training manual in 1994. The document notes that there is 'a need for a clear \& unreserved commitment to the promotion and protection of human rights and to the satisfaction of fundamental aspirations' ( $p$ 3). It is clearly stated that 'the greater knowledge and understanding of human rights will improve the actions and interventions of social work professionals' ( $p 3$ ). In the SDG document, there is specific reference to 'respect, protect and fulfil all human rights... \& fundamental rights are enjoyed by all without discrimination' (United Nations 2015 p 4). In addition, there is a very strong emphasis on gender equality and empowerment.

The SDG and social work values concur: For instance, the Agenda 2030 uses terms such as human dignity, inclusivity, respect diversity, equality and non-discrimination, empowerment, reliance, resilience, and self-help and realization of full potential. Social workers identify with these values for practice.

There is also a close parallel between social work target groups and those identified in the SDG agenda. Among the specific target groups are women, children, and youths, persons with disabilities, older persons, indigenous peoples, internally displaced people, migrants and refugees. In many countries including Malaysia, governments do not provide services to migrants and refugees as they are non-citizens and the country might not be a signatory to the 1951 Convention on Refugees and also the Convention on the Protection of the Rights of all Migrant Workers and Members of their Families. However, all countries face the implications of these target groups if they have ratified the Convention on the
Elimination of Discrimination Against Women (CEDAW) and the Convention on the Rights of Children (CRC).

\section{Malaysia and the SDGS}

Malaysia is a multi-ethnic, multi-lingual and multi-religious society of 30 million people which has experienced significant economic and social progress among the nations in South East Asia. Based on the figures released in the Eleventh Malaysia Plan (2015) by the Malaysia government, it is stated that 'Malaysia rose from the ranks of a low-income economy in the 1970s to a high middle income economy in 1992 and remain so today. Malaysia's national per capital income expanded more than 25-fold from US\$ 402 (1970) to US\$10, 796 (2014) and is well on track to surpass the US\$ 15,000 threshold of a high income economy by 2020' (11MP. p 1-3)

Malaysia endorsed this 2030 global action plan and at New York, the Malaysian Prime Minister has made an open pledge for its effective implementation in Malaysia and its role in the global and regional arena. PM Najib Tun Abdul Razak (2015) said in New York.

'Malaysia is absolutely committed to the post 2015 Agenda, the Social Development Goals and our aspirations to transforming the world by 2030 . For inclusivity and sustainable development have long been at the art of our transformation from a developing country to one that is on course to become a high income society by 2020 '. 'to reaffirm Malaysia's commitment to support \& implement the 2030 Agenda for sustainable development, a better future for all is not just within our grasp but it is also our duty to fight for it and I urge all present to join us in this noble and necessary endeavour'.

The Malaysian Government is therefore committed to SDGs over the next 15 years although there has not been any roadmap on priorities and implementation strategies. For the first 5 years, the indicators will no doubt be those as earlier released on May 21, 2015 in Parliament based on the Eleventh Malaysia Plan.

Malaysia did very well in fulfilling the MDGs but also indicated that there were some gaps in addressing urban poverty and inequality, concerns pertaining to quality of education and achievements as well as some emerging health issues which should be addressed in the SDGs. This was wellarticulated by Kamal Malhotra, the UN Resident Coordinator for Malaysia in his Preface to the 'Malaysia, The Millennium Development Goals at 2010' (UNDP 2011) namely 'while Malaysia has achieved the aggregate MDG objective of halving poverty- which fell from $17 \%$ in 1990 to $7 \%$ in 2000 and was $4 \%$ in $2009 \ldots$ nationally, income inequality remains high and has not substantially improved over the last 20 years. It is now time for Malaysia to prioritize relative poverty as a major 
policy axis, to ensure that it safeguards the welfare and wellbeing of marginalized groups and at a minimum, does not increase entrenched inequalities' ( $p$ vii-viii).

In this context, the SDG agenda 2030 with the 17 goals and the 169 targets is better poised to address the next level of development concerns. In this context, these 17 goals must be taken as a whole and the underlining philosophy and ethos of the SDGs must be upheld. A selective reading and compliance to some of the goals and targets will be ineffective. Therefore, the three dimensions of sustainable development must be taken together- namely economic, social and environmental in the context of human rights and inclusive development. The five key areas are critically important-people, planet, prosperity, peace and partnership. In addition for Malaysia, the guiding principles of the Universal Declaration of Human Rights (UDHR) and the Declaration on the Right to Development are formative to the realisation of a just society. Combating inequality and creating sustainable and inclusive societies are at the heart of the global transformation. The theme of 'no one will be left behind' (United Nations 2015 p 3) is our collective journey.

Amartya Sen (1999) clearly articulates a theory for practice which breaks the narrow view of development measured by growth of gross national product or with the rise of personal incomes. Professor Sen states 'development process in inclusive terms that integrate economic, social and political considerations' ( $p$ 8). Earlier in the book he notes that

'what people can positively achieve is influenced by economic opportunities, political liberties, social powers, and the enabling conditions of good health, basic education, and the encouragement and cultivation of initiatives. The institutional arrangements for these opportunities are also influenced by the exercise of people's freedoms, through the liberty to participate in social choice and in the making of public decisions that impel the progress of these opportunities' ( $p 5$ )

Therefore, in Malaysia, the SDG's must not just be viewed in a narrow or selective way, but in a holistic and inclusive way which empowers the people to realise their full potential through their exercising of the economic, social and cultural rights as well as their civil and political rights. This approach is both an opportunity for Malaysia but at the same time a challenge as we have in the past placed more emphasis on socioeconomic growth and at times supressing personal liberties and environment sustainability for economic and income growth.

\section{Malaysia's Eleventh Malaysia Plan and SDGs}

The Malaysian Government's development policy plans via the Eleventh Malaysia Plan (11MP) for inclusive development have some resemblance to the SDG-Agenda 2030 for sustainable development. There are some parallels between SDG (15 years) and 11MP (5 years: 2016-2020). The 11MP was tabled in Parliament on May 21, 2015 by Prime Minister Najib. He highlighted the place for the 'capital economy' on the one hand and the 'people economy' on the other. He reiterated that 'the people (the rakyat) will be the centre piece of all development efforts'.

In the 11MP foreword, the Prime Minister called on all Malaysians to join is the 'last leg of our momentous journey of becoming an advanced nation'. He lays a twin emphasis of inclusiveness and sustainability. Some key features of the 11MP is the Malaysia Wellbeing Index and that the target of a high income society (US\$ 15,000 is for all Malaysians implying 'all segments of society irrespective of geography, ethnicity or income level' (p 1-6). The sixth strategic thrust has some overlap with the SDGs as people, economy and planet are at the centre of the 11MP. These six core areas are the following: enhancing inclusiveness towards an equitable society, improving well-being for all, accelerating human capital development for an advanced nation, pursuing green growth for sustainability and resilience, and strengthening infrastructure to support economic expansion and finally re-engineering economic growth for greater prosperity.

\section{Inclusive Development}

The inclusive development agenda is a concept welldeveloped in the 11MP, and this is also a key theme in the SDGs. In the Malaysian context, inclusive development means that development is for all Malaysians. There are so many references in the $11 \mathrm{MP}$ towards this end of reassuring that all sections of Malaysia society has a place. This term for 'all Malaysians' or 'irrespective of ethnicity or race' appears eight times in Chapter 1 of the Plan, relevant page numbers (see pages 1-1. 1-4, 1-6, 1-8, 1-12,1-17, 1-18). There are phrases like 'Building a better Malaysia for all Malaysians'. The 11MP places people as the centrepiece (p 1-6). 'All segments of society irrespective of geography, ethnicity or income levels are expected to experience an increase in their income and wellbeing' ( $p 1-6)$. 'The goal is nothing less than a better quality of life for all Malaysians' (p 1-6). 'To ensure that all Malaysians are able to participate in and benefit from this growth...' (p 1-8). '... protect all Malaysians equally' (p 1-17). 'Inclusiveness so that no Malaysian is left behind, improved well-being for all, human capital development that is future-proof' (p 1-18). This assurance is important, and therefore, all sections have a place and share in the prosperity of the land.

Inclusive development is set within a policy statement that 'people are at the heart of development'. This is clearly described and consistently highlighted throughout the 11MP document namely that economic growth is for the benefit of the people of Malaysia. This clearly implies that it is not in the interest of a few but in the interest and name of all the people. 
The Eleventh Malaysia Plan indicated that 'people are the centre piece of all development efforts' ( $p$ i). This is a significant policy declaration. All agencies and institutions must set this as their key public policy agenda and ensure that this becomes the overriding theme.

There is also an acknowledgment that there is a two pronged approach in economic development namely a commitment to 'People Economy' as well as 'Capital Economy'. This likewise is a significant public policy declaration. Often, we will see the conflicts of these two economies, and therefore, we need institutional frameworks like social impact assessment instruments as well as grievances resolving mechanisms. One such example is the SUHAKAM (2013) Human Rights Commission of Malaysia's 'Report of the National Inquiry into the land rights of Indigenous people' which documents the human rights abuses and violations on indigenous people land rights. In a similar way, there are issues and concerns of the urban poor are documented by both Lim Chia Ying (2014) and Tan (2015). Government must address these shortfalls through effective remedial and complaint mechanism so as to mitigate these negative aspects.

However, concepts like people economy and that the public sector agencies will be 'Citizen-centric public services' as described in the 11MP is a step forward to make public sector services more accessible. This is a key for delivery that the civil service will see citizens as its clients so that the people at the bottom will be effectively served. However, many of the Bumiputra minorities and other ethnic minorities are not confident that they are included. This is where the delivery agencies must reach out in empathy and compassion.

This clearly is a challenge for social work practitioners in Malaysia. There must be a clear monitoring mechanism to ensure that this takes place including a hand-holding process and social preparation for the B40 to readily participate. Counter services and empathy of front line staff are most essential for the B40 to feel the caring nature of the State. Many experience the opposite and therefore civil service staff training and capacity building must be organised to address these concerns. The content of these training programs could build on the need to understand the diversity of the communities and their needs. Therefore, we need to assist and ensure that all Malaysians will experience the professional quality of the service that they rightly deserve.

\section{Bottom 40 (B40) Is Defined}

In the past development plans, the major consideration was given to ethnic or racial categories; however, in the 11MP, there are clear class or socio-economic categories cutting across both ethnic and racial categories. Based on the 2010 Census report 'the total population was 28.3 million of which $91.8 \%$ were Malaysian citizens and $8.2 \%$ were non-citizens. Malaysian citizens consist of the ethnic groups Bumiputera
$(67.4 \%)$, Chinese $(24.6 \%)$, Indians $(7.3 \%)$ and others $(0.7 \%)$ '. The Bumiptra term meaning 'sons of the soil' includes the ethnic Malays and the natives of Sabah and Sarawak including the aboriginal community of Malaysia.

The term B40 is well-developed in the 11MP. There is also a specific reference to B40 in the 2030 Agenda namely in Goal 10:1. In the 11MP too, there is a clear explanation of this term which has a class significance as opposed to ethnic, racial or religious. The social mobility objective is of moving the B40 higher up on the socio-economic ladder though better educational and training opportunities and increased income. There is therefore a policy outcome objective and target of moving people up the socio-economic ladder.

The B40 community in the 11MP is defined as a household with a mean monthly income of RM2, 537.00. It is noted that there are 2.7 million people in the B40 category (11MP p 112). Of these, $56 \%$ are in urban and the remaining $44 \%$ are in rural areas. Of these, $68 \%$ are Bumiputeras and the remaining $32 \%$ non-Bumiputeras (among the Malaysians of Indian and Chinese origin) (11MP p 3-12). It is important to note that B40 concerns are urban poor concerns. This is as a result of urbanisation with sizable movement of people from rural to urban locations in search for jobs and better quality of life. It is important to remember that $32 \%$ of the B40 come from the ethnic minorities who must have equal access to public sector social development programs.

While we recognise that Malaysia has had an outstanding track record in poverty eradication, the new challenge is rising inequalities within and among the various ethnic communities in Malaysia. This theme is well-developed by Tan Sri Kamal Salih (2013) and also by Muhammed Abdul Khalid (2014). Kamal focuses on income, growth, inequality and poverty. In his work, Khalid addresses serious issues of rising inequality as well as reviewing measurement of wealth moving beyond income to assert both financial and property. In this context of moving beyond absolute poverty and focusing on inequality with a focus on the Bottom, $40 \%$ as highlighted in the Eleventh Malaysia Plan (11MP) and the SDG Agenda 2030 is of great importance.

\section{SDGS and Malaysia's Human Rights Commitments}

Malaysia has ratified three UN Conventions, namely the Convention on the Rights of Children (CRC), Convention on the Elimination of all forms of Discrimination Against Women (CEDAW) and the Convention on the Rights of persons with Disabilities (CPRD). All three conventions have direct relevance to both SDGs and social workers in Malaysia as they are the key target groups social workers are working with.

Malaysia is also a signatory to a number of declarations. While declarations are different from conventions which are binding, declarations highlight the aspirations of a UN member state. In this context, one significant and relevant 
document Malaysia has signed is the UN Declaration on the Rights of Indigenous People (UNDRIP).

Social Workers in Malaysia have not played an active role in ensuring compliance from the State agencies in fulfilling their obligations. This role is well-played by human rights activists and human rights organisations including rightbased women's groups. In a similar way, social workers and their associations were not really active in the Universal Periodical Review Process (UPR) which was led by human rights activist groups including those working on gender. However, it must be noted that from an SDG perspective, this human rights discussion is very important as human rights are a key component of the SDGs. Therefore, holding Malaysia to a global standard and compliance is of utmost importance.

Let us review the three conventions and compliance concerns in the Malaysian context.

\section{$C R C$}

Basic information on the CRC and Malaysia is from the UNICEF website (UNICEF 2015). Malaysia ratified the CRC in 1995 with a number of 'reservations' to the provisions of the CRC. In the UN system, a 'reservation' allows a State to disagree with a provision in a treaty. The State can still approve the treaty as a whole, with reservations serving as exceptions.

Reservations to CRC Articles 1, 2, 7, 13, 14, 15, 28(1)(a) and 37 were put in place since these Articles were said to "not conform with the Constitution, national laws and national policies of the Government of Malaysia, including the Syariah law'. While the Government has lifted some of these reservations, others remain, namely Article 2 on non-discrimination, Article 7 on name and nationality, Article 14 on freedom of thought, conscience and religion, Article 28(1)(a) on free and compulsory education at primary level, and Article 37 on torture and deprivation of liberty. Governments that ratify the Convention on the Rights of the Child and its Optional Protocols must report to the Committee on the Rights of the Child, the body of experts charged with monitoring a country's implementation of these human rights treaties. These government reports must outline the situation of children in the country and explain the measures taken to realise and protect their rights.

Malaysia submitted her first report to the Committee in 2006; however, the second report which was due in 2012 is still pending. On the first report, the CRC Committee recognised the Government's serious attempts to comply with the CRC, especially through the enactment of the Child Act in 2001. The Committee submitted its Concluding Observations to Malaysia in 2007, which included the following recommendations: First, review and abolish Malaysia's reservations to the CRC. Second, ratify the two Optional Protocols and other international laws. Third, review Malaysia's dual legal system
(Civil and Syariah) as some domestic laws are obstacles to the realisation of the CRC in Malaysia. Fourth, review and reform domestic laws such as the Essential (Security Cases) Regulations 1975. Fifth, abolish capital punishment for children. Sixth, review the Children and Young Persons (Employment) Act 1966 to ensure that acceptable conditions of work are clearly and strictly defined to comply with international labour standards.

\section{CEDAW}

The information and analysis on CEDAW were secured from Women's Aid Organisation (WAO) which is documented below. Malaysia ratified CEDAW on July 5, 1995. The Government of Malaysia submitted its initial and second periodic reports on the status of women in the country at the 35th CEDAW session at the United Nations in New York on May 24, 2006. The Malaysian Government was represented by a delegation led by the Ministry of Women, Family and Community Development and six representatives from women's NGO groups. Malaysian NGOs prepared a Shadow Report. Upon the delay of the third report, the CEDAW Committee requested that a combined third and fourth report be submitted by the Malaysian government in August 2008. This report is still outstanding and delayed by over 7 years.

The Malaysian Women NGOs provided a report in 2012 entitled 'CEDAW \& Malaysia: Malaysian NGO Alternative Report assessing the Government's progress in implementing CEDAW' (WAO: 2012). According to this report, while there have been changes in government policy since 2006 , there has not been a substantive change in the status of women's human rights in the country, at the national level in Malaysia, whereby convenient cultural and religious excuses are offered to explain the lack of acceptance of the principle of the universality of women's human rights. In July 2010, the government removed its reservations to CEDAW Articles 5(a), 7(b) and 16(2). However, reservations still remain on five CEDAW Articles: 9(2), 16(1)(a), 16(1)(c), 16(1)(f) and 16(1)(g).

The central issue is that the Malaysian government has not incorporated the CEDAW Convention into national law. There is no gender equality legislation in place providing for the comprehensive realisation of substantive equality of women with men in both public and private spheres of life. The overarching concerns expressed by the CEDAW Committee at the Malaysian government's 2006 review session continue to be issues of concern. These include the lack of clarity on the meaning of equality and non-discrimination, the lack of a legal framework for equality and non-discrimination, the lack of data disaggregated by gender and the neutrality of the Malaysian government's 5-year overarching Malaysian Development Plans. The Women's NGOs note that the government is to be commended on lifting its reservations to three 
CEDAW Articles: 5(a), 7(b) and 16(2). However, little has been done to achieve the practical realisation of the intent of these Articles, as there has been no change in law or policy and the status quo remains. The NGOs highlight that the government has not removed nor given any intension to remove the following five reservations in CEDAW Articles: 9(2), 16(1)(a), 16(1)(c), 16(1)(f) and 16(1)(g). The government has not given any indication of an intention to remove its reservations to these Articles.

Although Article 8(2) of the Federal Constitution was amended to include gender as a prohibited ground for discrimination, this was not accompanied by a comprehensive review of all laws, including provisions within the Federal Constitution itself, which continue to be discriminatory. The government has not incorporated the CEDAW Convention into national law. There is no gender equality legislation in place providing for the comprehensive realisation of substantive equality of women with men in both public and private spheres of life.

\section{Convention on the Rights of Persons with Disabilities}

Malaysia signed the CRPD on April 8, 2008 and ratified it on July 19, 2010. In the UN website UN (2006), it is recorded that 'Malaysia acknowledges that the principles of nondiscrimination and equality of opportunity as provided in articles 3 (b), 3 (e) and 5 (2) of the said Convention are vital in ensuring full and equal enjoyment of all human rights and fundamental freedoms by all persons with disabilities, and to promote respect for their inherent dignity, which shall be applied and interpreted on the basis of disability and on equal basis with others. Malaysia declares that its application and interpretation of the Federal Constitution of Malaysia pertaining to the principles of non-discrimination and equality of opportunity shall not be treated as contravening articles 3 (b), 3 (e) and 5 (2) of the said Convention'. Furthermore, it is recorded that 'Malaysia recognizes the participation of persons with disabilities in cultural life, recreation and leisure as provided in article 30 of the said Convention and interprets that the recognition is a matter for national legislation'.

Malaysia also held in reservation two articles and the UN web records, "the Government of Malaysia ratifies the said Convention subject to the reservation that it does not consider itself bound by articles 15 and 18 of the said Convention'.

\section{Concern with Malaysia's Compliance and Reports}

Malaysia has ratified three of the nine core conventions, and all three are more in the realm of economic and social aspects. This is good but the way reports are not submitted on time and the delays reveal either Malaysia is not committed or that it does not have the capability to undertake monitoring, documentation and report writing. Therefore, with this track record, there might be serious concerns with the SDG reporting and the commitment towards compliance and benchmarking with global standards and practices.

The agency responsible for the reports and reporting to the treaty bodies in the above three cases is the Federal agency, the Ministry of Women, Family \& Community. The delays in report submission could imply lack of resources and capacity, and therefore, these matters must be further studied. Adequate resources must be made available including recruitment of staff and their capability building. In the interim, the Government could enlist the services of university academics and write impact assessment and reports. Social workers can play an active advocacy and lobby role to ensure compliance to global and universal standards. This will enhance social work practice. The Malaysian Association of Social Workers and the Malaysian Association for the Schools of Social Work could strategically play a major role in assisting the agencies to enhance practice as well as undertake to do the relevant documentation so as to benchmark based on their international status.

\section{The Universal Periodical Review}

The Universal Periodic Review (UPR) is a peer review system introduced by the United Nations where every member state will undergo review of its human rights situation. This Statedriven process provides an opportunity for each State to declare what actions it has taken to improve the human rights situation at home to fulfil its human rights obligations. The process provides stakeholders opportunity to provide their analysis and assessments including recommendations for improvements. This is a very transparent process with all information accessible to all.

Malaysia underwent the UPR in 2009 and more recently on Oct 24, 2013. The latter UPR drew much attention in Malaysia especially with the differing views of political and civil society groups. The Universal Periodic Review held on Oct 24, 2013 at the Human Rights Council in Geneva provides a good assessment of the human rights standing of Malaysia based on global human rights benchmarks and instruments. One hundred and four countries spoke on the Malaysian situation and there are 249 recommendations (in 232 paragraphs). Some individuals and groups from Malaysia claimed that the UN session on Human Rights sought to discredit Islam and promote sexual freedoms (Shazwan Mustafa 2014).

However, this is not reflected in the detailed analysis of the 249 recommendations. Of these recommendations, 16 were provided by ASEAN countries, 40 by G20 countries, 75 by OIC countries and the remaining 118 by other UN member states. The themes could be divided into nine main categories namely international agreements (80 recommendations), police, courts and 
punishment (31 recommendations), special groups (70 recommendations), health care (15 recommendations), freedom of expression (13 recommendations), respect and tolerance (13 recommendations) education ( 9 recommendations), income inequality and poverty ( 8 recommendations), and general (10 recommendations).

The Society for the Promotion of Human Rights (PROHAM) hosted four Roundtable Discussions to review the submissions made for the UPR discussions as well as the outcome document and Malaysia's response. The findings are to be published in 2016 in a booklet entitled 'Human Rights Priorities for Malaysia' and is an attempt to capture the key issues, concerns and recommendations for the Malaysian agenda'. A number of the findings from this report are listed below.

1. Appreciation of Malaysian action: The Malaysian Government has played an active role in human rights matters at the regional-ASEAN level and at the International level especially in the promotion of Moderation as a key component of international relations and conflict management. Malaysia took a serious approach in addressing the UPR matters through the UN mechanism. Malaysia's open commitment to develop the long delayed National Human Rights Action Plan is a step in the right direction.

2. Major concerns on rejected recommendations: While noting this aspect of active Malaysian involvement in the UPR process; however, there are some major concerns in the recommendations from UN member states that Malaysia either rejected or did not consider. It is noted that Malaysia adopted the more straightforward or weaker/ softer human rights matters. Malaysia in not adopting the more substantive aspects of human rights reveals its weak commitment and lip service to human rights based on the bench mark of international human rights norms.

3. Among the rejected recommendations are the following major rejects: Malaysia's unwillingness to ratify major human rights conventions. Malaysia's inaccurate portrayal that there is no 'conflict of competence' between the Civil and Syariah Courts in Malaysia based on Federal Constitution Article 121 (1A). Malaysia's rejection of the Royal Police Commission's recommendation in not wanting to establishment the IPCMC and its insistence that the EAIC plays that role is in denial of the major human rights violations committed by the Malaysian Police. Malaysia's position on the Suhakam reports on land rights of indigenous people.

4. The Way Forward-Human Rights Priorities for Malaysia: There is a need to strengthen stakeholder participation and consultation. Engagement with all parties especially civil society is imperative. It was noted that this openness was lacking in the recent UPR process where engagement with civil society was selective. There is a need to strengthen SUHAKAM as the national human rights institution with adequate powers to ensure that agencies comply with their findings and the power to take human rights violators to court without the approval of the Attorney General. In this context too, to mandate Parliament to allocate time to debate the annual Human Rights Report and a permanent parliamentary committee on human rights is established.

And finally, there is a need for political leadership and greater role played by elected members of parliament as well as those in public office. We have an impression that the UPR process within government is largely a civil service and bureaucrats' process and very little role played by parliamentarians and politicians in public office. Therefore, the human rights agenda must have an active parliamentary process as well as elected public officials in government. It is significant that Malaysia has made a public commitment to the establishment of the National Human Rights Action Plan. This is long overdue. Furthermore, the current committee working on this must be more inclusive and participatory. A more public dialogue approach must be adopted in the setting the priorities including active participation of civil society human rights organizations. There is a need to establish a People's Monitoring Group on the implication of the human rights commitments as a way of monitoring the commitments and implementation over the next few years leading to the third UPR review in 2017. The Malaysian Association of Social Workers could play an active role especially with regard to fulfilment of the ratification obligations, and it is to this we now turn.

\section{SDGS, Social Work Challenges and Opportunities in Malaysia}

Formal social welfare work began after the Second World War when the Colonial Administration in 1946 established the Department of Social Welfare. The Central Welfare Council was also established in the same year. According to Jayasooria (2000), "prior to this there was no organised welfare by the colonial administration. Welfare was organised and supported for a majority of people at the informal level, mainly the family. Voluntary organisations established by Christian missionaries also ran institutions for orphans, disabled people and the aged'. (p 63). The first of these was established in 1911 established a home for disabled people followed by St. Nicholas Home for the blind in 1926.

After independence from the British in 1957, we see the rise of State commitment and responsibility for social welfare and social work. Ismail Baba (1992) highlighting this development by noting the recruitment of both trained social workers and non-trained to carry out social work duties. He noted that 'in 1976-1977 almost $70 \%$ of welfare personnel 
were not trained in social work. Such a high ratio of untrained personnel has affected the image of the ministry, and also reflects poorly on the development and identity of the social work as a whole' ( $p$ 513). A fuller historical review of both social work practice and social work education is provided by Jonathan Parker forthcoming 2016 (Jonathan et al. 2016).

This situation has not really changed very much regards to social work professionals due to the understanding of social work as an act of compassion and caring. While this value is true, it should not negate the social work knowledge based and competencies needed. More local universities are now offering an undergraduate program in social work. The situation will change, but there is a need for a clear policy change on the part of the Federal government especially with regard to professional recognition which is currently lacking. The Malaysian Association of Social Workers have been lobbying for this and have been working with the Department of Social Welfare for the new legislation Social Workers Act and the licensing of the profession similar to that of other professionals like counsellors, teachers and nurses in Malaysia. A social workers competency standard setting framework has been developed but has not been mandated for practice. A draft bill has been prepared but there have been delays on this matter.

\section{Social Work Challenges}

In the Malaysian context, social workers have often narrowed their analysis of social needs to the micro level at the individual and family levels. This is due to a very strong orientation to casework as well as a majority of government appointed social welfare officers are busy processing application forms based on eligibility for the grant or service and not really focused on making a comprehensive assessment of the needs and issues so as to work with the clients for a range of intervention strategies. In a similar way, a majority of voluntary organisations are caught up with institutional, residential and day-care programs. Often, a community - based approach is neglected due to shortage of staff and resources. Therefore, the inter-connections are neglected for a very individual and family focus based on eligibility to access the services provided.

In a National Survey Report (MASW 2005) prepared by the Malaysian Association of Social Workers in 2005, it was revealed that $81.3 \%$ of the social workers who responded indicated that they saw their work as giving advice, $79.7 \%$ agreed that they were moralising on clients' actions, $81.3 \%$ were falling on their religious beliefs and $72.5 \%$ on personal opinion. A total of 433 social workers participated, and of them, only $14 \%$ had a qualification related to social work. This situation has not changed much over the years.

The professional identify is a major issue of concern in contemporary Malaysian society. This is because other professions find it easier to define themselves as counsellors, development workers, environmentalist, or human rights advocates; however, for social workers, many volunteers, public individuals and corporate people see themselves as providing a service or doing good unto others. This is further complicated due to the field of study, lack of defining social workers and their roles in Malaysian society. The Malaysian Association of Social Workers and the Malaysian Association of Schools of Social Work are undertaking a public campaign to educate the general public as well as the civil service to view social work as professional services which plays a major role in people and community development (MASW 2015).

There is very little policy research and advocacy work coming from both the public sector side and the voluntary sector. One major issue is personal and priorities of the agencies or organisations concerned to do their best within the resources they have. The situation is similar for human rights approach, as in this case, there are the added complication and challenge to confront the State which has political implications.

A majority of social workers in Malaysia tend to avoid a human rights approach due to the political implications and justice aspects which could be viewed as confrontational. Many voluntary organisations rely on public sector funding or from the general public, and therefore, any questioning of policies might be misconstrued as going against the government. While Malaysia has done well on the economic, social and cultural rights issues, however, on civil and political rights, it has been very conservative and has in recent years restricting both the democratic space and the voice for human rights.

In the area of environmental and sustainability concerns, there is a total neglect and therefore much has to be done in this context although human rights activities, development workers and environmentalist especially those working with indigenous people have been in the forefront of community development and social justice approaches.

\section{Opportunities for Social Workers}

While we have noted the current challenging social work environment in Malaysia, we also need to recognise the great potential of the SDG agenda which Malaysia has adopted as its policy framework for the next 15 years and has also acquiesced to the review process by submitting the periodical reports measuring the achievements and acknowledging the shortcomings for further action.

As social workers, we must study the SDGs and note with relevance how social work theory and practice can inform as well as draw on SDGs. The integrated, cross-cutting approach of SDG is a very suitable platform for social work practice in Malaysia. The multidimensional approach is holistic and therefore more realistic in addressing the core concerns of ordinary people. In a similar way the SDG also incorporates 
a human rights approach and social workers can utilise this framework as it has been endorsed by global leaders and nationally at the Malaysian context by the Prime Minister who made a global promise.

Two field studies were undertaken recently pertaining to urban poor communities. The first is the study of nine urban flat neighbourhoods where we saw the need for inter-ethnic and cross-cultural approach of social work practice lacking due to the way current practice is very ethnic oriented. Lim Chia Ying (2014) draws on some of the conclusions. In addition Kathleen Tan (2015) provides the wider context of ruralurban divide in modern Malaysia. Therefore, addressing concerns of the B40 community especially the urban poor requires our urgent attention, and social workers can facilitate community organising and undertake a stringer practice approach as advocated by Ling (2007) and Ling et al. (2014) utilising a cross-cultural social work method which is sensitive to cultural diversity. Adopting a stronger social work approach pertaining to group work and community work in practice in Malaysian society is of utmost importance.

The second field study is a recently completed unpublished study on high-risk youths in Malaysia which identified issues pertaining to competency standards at the grassroots level. This study was undertaken between 15th of April and 15th of October 2015 at the Iskandar region, Johore in two districts. It focused on the B40 neighbourhood level. The study identified the issues and concerns of high-risk youth especially in the Bottom 40 neighbourhoods through a series of dialogues held with agencies, young people and local community leaders. One of the major findings was 'that the government personnel deployed to do youth work at the community level or even agency level were not trained in related field. Many of these youth related officers are diploma holders but not in the related field of youth work or social work or community work or community mediation, poverty work, urban organising and other such streams. They lack the knowledge and competencies in addressing critical concerns of high-risk youth at the B40 community level'.

Addressing the concerns of young people in urban poor locations especially concerns of high-risk youths and familybased issues at the community levels including youth drop out from school or being sacked as well as youth underachieving educationally at school with anti-social behaviour is a major opportunity. Thus far in Malaysia, the Ministry of Education has only appointed school counsellors as well as the police have assigned an officer to the school as liaison officer in charge of community politicking. What they are lacking are social workers who can do complementary work of working with the young person in the context of the family and the local communities they live in.

In addition, the SDGs provide social workers a new role in monitoring and enhance implementation. There is a 15 -year agenda, goals, targets and indicators to achieve. Social workers in Malaysia can fill that gap in playing both a complementary role as well as an advocacy role. Academics from schools of social work must be more vocal publically as public intellectuals.

\section{Conclusion}

In this article, we explored the thrust of the SDGs and relate these to social work practice and human rights concerns with relevance to the Malaysian context. In doing these, we reviewed the parallel SDG ethos with that of social work values as well as the intervention charted as being holistic and integrated. The global social work community through its proactive initiative and documents on social work and social development is facilitating a positive social workers response.

We recognise many challenges for social work practice in Malaysia as well as potential possibilities over the next 15 years. There is now an opportunity especially as Malaysia is defining the framework for implementation. There is a vacuum among social sector delivery staff, agencies and organisations to adopt a SDG framework as Malaysia is committed to meet the goals, targets and indicators in the short term by 2020 and in the long term by 2030 . Over the next 15 years, social workers can refine their roles based on the SDG 2030 agenda for holistic development taking both human rights and the environment at the heart of both human services and social justice through social work practice.

\section{References}

Baba, I. (1992). Social Work- An effort towards building a Caring Society" IN Cho Kah Sin \& Ismail Muhd Salleh (1992) Caring Society, Emerging Issues and Future Directions (pp. 509-530). Kuala Lumpur: ISIS.

Census Report - Malaysia 2010 : https://www.statistics.gov.my/ index.php? $\mathrm{r}=\mathrm{column} / \mathrm{ctheme} \& \mathrm{menu} \mathrm{id}=\mathrm{L} 0 \mathrm{pheU} 43$ NWJwRWVSZk1WdzQ4TlhUUT09\&bul_id=MDMxdHZjWT k1SjFzTzNkRXYzcVZjdz09

Eleventh Malaysian Plan (11MP) 2016-2020. (2015). Anchoring Growth on People. Kuala Lumpur: Government Printers.

IFSW (2014) Global Agenda for Social Work and Social Development http://cdn.ifsw.org/assets/ifsw_23031-6.pdf

Jayasooria, D. (2000). Disabled People, Citizenship \& Social Work, The Malaysian Experiences. London: ASEAN Academic Press.

Jonathan, P., Sara Ashencaen, C., \& Azlinda, A. (2016). "Treading the long path: social work education in Malaysia" Forthcoming chapter in new book.

Kamal, S. (2013). Development and Inequalities. In search of a New Economic Paradigm using the Malaysian case. Bangi: UKM.

Kathleen Tan (2015) Bridging the urban rural divide http://www. theantdaily.com/Main/Bridging-the-urban-rural-divide

Khalid, M. A. (2014). The Colour of Inequality, Ethnicity, class, income and wealth in Malaysia. Petaling Jaya: MPH. 
Lim Chia Ying (2014) Poverty: hope beyond handouts http://www. thestar.com.my/lifestyle/features/2014/01/02/poverty-hope-beyondhandouts/

Ling, H. K. (2007). Indigenising social work: research and practice in Sarawak. Petaling Jaya: SIRD.

Ling, H. K., Martin, J., \& Ow, R. (2014). Cross-Cultural Social Work, Local \& Global. South Yarra: Palgave Macmillian.

MASW (2005) National Survey Report on Current social work practice among social service organisations in Malaysia. MASW: June 2005

MASW (2015) Unpublished Annual Report presented at the 2015 AGM June 13, 2015

Razak, N. T. A. (2015). Speech: UN Sustainable Development Summit 2015 General Assembly. Reference, https://www.youtube.com/ wat ch ? v=k0 - R 39 O F P I I \& l is t=P L G S R J 9 j A xd kv 1cyD7hrSVeU3QSpNYcoTW.

Sachs, J. D. (2015). The age of sustainable development. New York: Colombia University Press.

Sen, A. (1999). Development as Freedom. New York: Alfred Knopf.

Shazwan Mustafa Kamal (2014) "Home Ministry ban signals crackdown on civil society, say Comango reps" - See more at: http://www. themalaymailonline.com/malaysia/article/home-ministry-bansignals-crackdown-on-civil-society-say-comango-reps\#sthash. DHRqwy02.dpuf

SUHAKAM (2013) Report of the National Inquiry into the Land Rights of Indigenous Peoples. SUHAKAM: Kauala Lumpur

United Nations (2015), "Transforming our world: The 2030 Agenda for sustainable Development". https://sustainabledevelopment.un.org/ post2015/transformingourworld
UN (2006) Convention on the Rights of Persons with Disabilities, Declarations and Reservations: Malaysia https://reaties.un.org/ Pages/ViewDetails.aspx?src=IND\&mtdsg_no=IV-15\&chapter= 4\&lang=en\#EndDec

UNDP (2011). The Millennium Development Goals at 2010. Kuala Lumpur: UNDP.

UN: Rio plus 20: UN gathering at Rio de Janeiro, Brazil, from 20-22 June 2012 http://www.uncsd2012.org/content/documents/727The\% 20Future $\% 20$ We $\% 20$ Want $\% 2019 \% 20 J u n e \% 201230$ pm.pdf

UN: The High Level Panel on the Post-2015 Development Agenda today released "A New Global Partnership: Eradicate Poverty and Transform Economies through Sustainable Development". http:// www.post2015hlp.org/the-report/

UN : Open Working Group proposal for Sustainable Development Goals. https://sustainabledevelopment.un.org/focussdgs.html

UN Secretary General Report Synthesis Report "The Road to Dignity by 2030 http://www.un.org/disabilities/documents/reports/SG Synthesis_Report_Road_to_Dignity_by_2030.pdf

UNICEF (2015) Child rights in Malaysia A Protective Environment for Children. http://www.unicef.org/malaysia/childrights malaysiaoverview.html

WAO (2012), CEDAW \& Malaysia: Malaysian NGO Alternative Report assessing the Government's progress in implementing CEDAW. WAO:PJ http://wao.org.my/file/file/Malaysian $\% 20 \mathrm{NGO} \%$ 20CEDAW\%20Alternative\%20Report\%202012\%206MB.pdf 